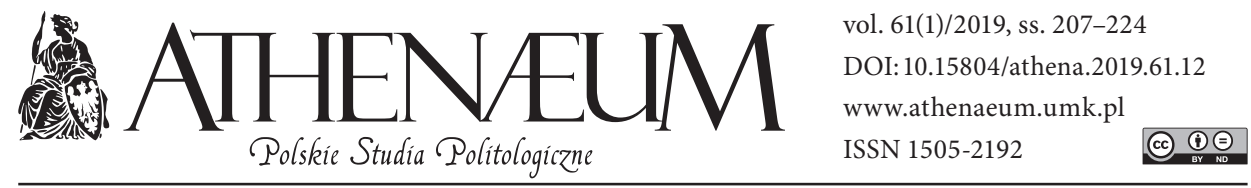

\title{
ROSJA-ASEAN: NOWE KONCEPCJE WSPÓŁPRACY I STARE OGRANICZENIA
}

\author{
RUSSIA-ASEAN: NEW CONCEPTS OF COOPERATION \\ VS. PAST LIMITATIONS
}

Małgorzata Pietrasiak* 구

\begin{abstract}
ABSTRAKT
W artykule została przedstawiona ewolucja stosunków Rosji ze Stowarzyszeniem Narodów Azji Południowo-Wschodniej ASEAN, ze szczególnym uwzględnieniem relacji współczesnych. W drugiej dekadzie XXI w. Rosja zintensyfikowała kierunek azjatycki swojej polityki zagranicznej. W opinii wielu ekspertów ta polityka przekłada się w zbyt oczywisty sposób na relacje z Chinami, przez co Rosja może uzależnić się od tego mocarstwa i być postrzegana jako niesamodzielny gracz regionalny. Podejmowane są zatem działania, aby zdywersyfikować partnerów. ASEAN jest jednym $\mathrm{z}$ bardziej perspektywicznych, choć jednocześnie trudnych kierunków. Perspektywicznych ze względu na dynamikę rozwoju oraz aktywne uczestnictwo $\mathrm{w}$ regionalnych, jak również transregionalnych działaniach, trudnych, bowiem mimo deklaracji rozwój stosunków między ASEAN i Rosją postępuje powoli. Nową koncepcją rosyjską, która ma ożywić współpracę a jednocześnie pokazać, że Rosja może być niezależnym graczem regionalnym,
\end{abstract}

The article examines the evolution of political ties between Russia and the Association of Southeast Asian Nations (ASEAN) with the special regard to contemporary relations. In the $2^{\text {nd }}$ decade of the $21^{\text {st }}$ century Russia intensified the "Asian direction" of its foreign policy. A lot of political pundits claim that this strategy has an impact on relations with China, and can lead to the growing reliance on Beijing. Therefore Russia, which may be perceived as a dependent regional player, takes actions to diversify political partners. Southeast Asia is one of the most prospective but difficult regions to establish a network of alliances. Prospective - because of its dynamic development, and participation in regional and transregional initiatives. Difficult, cause despite many declarations, improvement of the relations between the ASEAN and Russia has been advancing at a slow pace. The concept of Great Euroasia, which is a typical trend of "new regionalism", can revive

* Uniwersytet Łódzki, Wydział Studiów Międzynarodowych i Politologicznych. 
jest projekt Wielkiej Euroazji, który jest zgodny $\mathrm{z}$ aktualnymi trendami „nowego regionalizmu”.

Słowa kluczowe: stosunki międzynarodowe; Rosja; ASEAN; regionalizm; Wielka Euroazja cooperation, making Russia independent regional player.

Keywords: international relations; Russia; ASEAN; regionalism; Greater Eurasia

\section{ZAŁOŻENIA TEORETYCZNE ANALIZY}

Stowarzyszenie Narodów Azji Południowo-Wschodniej ASEAN dla potrzeb niniejszego artykułu będę traktowała jako gracza unitarnego, mając jednocześnie świadomość pewnych ograniczeń takiego podejścia. Są to zarówno rozbieżne interesy państw członkowskich wobec operujących w regionie wielkich graczy, jak i ich zróżnicowanie.

Takie podejście znajduje zastosowanie u niektórych badaczy zajmujących się sposobem funkcjonowania ASEAN, dla których Stowarzyszenie należy traktować jako wspólnotę. Na przykład Amitav Achrya nazywa Stowarzyszenie „budującą się wspólnotą bezpieczeństwa”, Tobias Nischalke „wspólnotą dla wygody” (Ha, 2008). Rodolfo Soverino nazywa to wspólne działanie „skoncentrowanym podejściem" (Severino, Thuzar. 2012). Dyplomacja ASEAN zakłada centralizm (ASEAN centrality), a w tym określeniu zawarte jest podejmowanie decyzji na zasadzie konsensusu, uwzględnienia interesu wszystkich członków i silnego poczucia suwerenności każdego z członków. Centralizm ASEAN polega na tym, że wokół Stowarzyszenia jako osi zbudowane są i powstają nowe ugrupowania, formaty dialogu, takie jak: ARF(ASEAN Regional Forum) ASEAN+, EAS (East Asia Summit), a wszystkie one działają na podstawie ASEAN way - zbioru zasad wartości i norm zaakceptowanych przez wszystkich dziesięciu uczestników.

Z punktu widzenia ASEAN obecność Rosji w regionie należy postrzegać przez pryzmat budowania równowagi między najważniejszymi mocarstwami regionalnymi, przede wszystkim USA i Chinami, ale również Japonią, Australią i Indiami. Budowanie równowagi sił - kategoria teorii realizmu będzie, w przypadku relacji Rosji z ASEAN, uzupełniona kategorią asekuracji (hedging; Karolev, 2018), bowiem możliwość oddziaływania jej na otoczenie międzynarodowe różni się od możliwości Stanów Zjednoczonych, Chin czy nawet Indii, ze względu na słabość powiązań gospodarczych i wpływów politycznych. Zatem jej sposób działania polega na poszukiwaniu alternatywnych możliwości, multiplikowaniu interesów i niedokonywaniu bezpośredniej presji na strony uczestników 
stosunków regionalnych. Tak właśnie działa Rosja w regionie Azji Południowo-Wschodniej i takie (z niewielkimi odstępstwami) są wobec niej oczekiwania członków Stowarzyszenia. Możliwości wkroczenia w bipolarny układ sił w tym regionie Rosja nie ma. Geopolityczne i geoekonomiczne aspiracje Rosji pozwalają spojrzeć na relacje Rosja-ASEAN także pod kątem umacniania własnej pozycji w regionie oraz budowy nowego podmiotu regionalnego - Syberii i Okręgu Dalekowschodniego (geograficznie Rosyjski Daleki Wschód, RDW).

Teoretyczną podbudową analizy będzie teoria nowego regionalizmu, która - jak słusznie zauważa Heiner Hanggi - w odróżnieniu od większości teorii zajmujących się rolą i znaczeniem czynników determinujących regionalizm, zajmuje się stosunkami międzyregionalnymi. Heiner Hanggi używa pojęcia interregionalizmu (Hanggi, 2000) i wyróżnia 3 formy współpracy interregionalnej: relacje między regionalnymi ugrupowaniami, biregionalne i transregionalne ugrupowania oraz hybrydy takie jak relacje między regionalnymi grupami a pojedynczymi państwami. Przykładami są: Unia Europejska-Chiny, Unia Europejska-Japonia, czy przedmiot analizy ASEAN-Rosja.

Cechą charakterystyczną procesów w Azji Wschodniej jest to, że dotyczą praktycznie regionalizacji ekonomicznej, natomiast polityczna współpraca jest nieformalna, opiera się na uzgodnieniach, konsensusie i metodach, które można zaliczyć do arsenału z grupy soft power. Regionalizm rozwija się wokół subregionów (ASEAN) lub schematów transregionalnych (Asia-Pacific Economic Co-operation, APEC, ARF, EAS). W odróżnieniu od „nowego regionalizmu” te procesy w Azji Wschodniej są nazywane „otwartym regionalizmem”. W artykule zostanie udowodnione, że współpraca ekonomiczna Rosji i ASEAN, najbardziej charakterystyczna dla regionu, zdaniem Hanggi, pozostaje daleko w tyle, mimo licznych deklaracji przyspieszenia. Za to idea tworzenia relacji transregionalnych oraz budowa nowej architektury bezpieczeństwa pozostaje w centrum zainteresowania obu stron.

Zatem w artykule, korzystając ze spojrzenia obu klasycznych paradygmatów badania stosunków międzynarodowych, omówiona zostanie rosyjska idea tworzenia relacji transregionalnych $-\mathrm{z}$ wykorzystaniem istniejącej organizacji ASEAN - oraz relacje hybrydowe, tj. między Rosją i ASEAN. Z jednej strony będzie to spojrzenie realistyczne, podkreślające wartość realizacji interesu narodowego/grupowego (w przypadku ASEAN), podkreślenie tradycyjnych zasad budowania relacji między podmiotami opartymi na suwerenności, niezależności, idei równowagi sił. Z drugiej strony dążenie do doskonalenia współpracy za pośrednictwem multilateralnych form tradycyjnie będzie nawiązywało do 
liberalnych zasad funkcjonowania uczestników stosunków międzynarodowych. Wartości, takie jak budowanie relacji na zasadzie poszanowania suwerenności oraz dążenie do świata multilateralnego, są bardzo atrakcyjne dla obu partnerów dialogu.

\section{HIPOTEZY BADAWCZE:}

1. Rosja jest elementem geopolitycznej gry w regionie Azji Południowo-Wschodniej i działa na rzecz integracji regionu z jej obecnością oraz stabilizacji, która dla niej jest warunkiem niezbędnym dla rozwoju w sytuacji zamrożenia relacji z UE.

2. Rosja jest postrzegana jako bliski sojusznik Chin, ale w odniesieniu do ASEAN Chiny i Rosja nie wypracowują wspólnej strategii, w niektórych obszarach ich interesy są sprzeczne.

3. W porównaniu $\mathrm{z}$ innymi uczestnikami dialogu w formacie ASEAN+ Rosja, nie jest ona znaczącym partnerem. Taki status drugoplanowej roli zostanie utrzymany, jeśli strategiczny plan budowy makroregionu euroazjatyckiego z udziałem ASEAN nie zostanie podjęty i jeśli wizerunek pozostającego z boku gracza się nie zmieni.

\section{EWOLUCJA WZAJEMNYCH KONTAKTÓW}

Początek stosunków ASEAN-Rosja sięga czasów zakończenia okresu zimnowojennego. W $1991 \mathrm{r}$. rosyjski wicepremier został zaproszony na doroczne spotkania ministrów spraw zagranicznych ASEAN. W 1994 r. między ASEAN a Rosją zostało ustanowione partnerstwo konsultatywne. Rosja stała się członkiem założycielem ASEAN Regional Forum (ARF) w 1994, zanim jeszcze została oficjalnym partnerem dialogu razem z Chinami i Indiami w 1996 r. Rozpoczął się wówczas proces konstruowania bazy instytucjonalnej. Relacje z Rosją są skonstruowane na tej samej podstawie co z innymi partnerami dialogu: USA, Kanadą, Indiami, Republiką Korei, Japonią i UE. W czerwcu 1997 r. powstał Wspólny Komitet Współpracy ASEAN+Rosja (ASEAN-Russia Joint Cooperation Committee ARJCC) oraz Komitet ds. Zarządzania (ASEAN-Russia Joint Management Committee). To, co wyróżniało dialog ASEAN z Rosją od innych i stwarzało spore ograniczenia, to brak Funduszu Dialogu, będący wynikiem opieszałości 
działań. Utworzono go dopiero w 2007 r. (ASEAN-Russian Federation Dialogue Partnership Financial Fund). Niestety fundusz nie był zbyt efektywny. W 2007 r. Rosja zasiliła go kwotą 500 tys. USD. W 2010 r. wkład rosyjski do Funduszu wyniósł 1,75 mln USD. Rosja zaoferowała 1,5 mln USD rocznie, poczynając od 2011 r., co nadal było sumą niewystarczającą.

W listopadzie 2004 r. Rosja stała się stroną Traktatu o Wzajemnych Stosunkach i Współpracy (Treaty of Amity and Cooperation TAC) oraz poparła wysiłki ASEAN utworzenia w ASEAN strefy wolnej od broni atomowej i wzmocnienia regionalnego i globalnego bezpieczeństwa (The Southeast Asian Nuclear-Weapon-Free Zone Treaty SEANWFZ; Overview ASEAN-Russia Dialogue relations). Gdy podpisano Kartę ASEAN, która weszła w życie w styczniu 2009 r., Rosja zaczęła akredytować swoich ambasadorów przy ASEAN. Od sierpnia 2017 r. przedstawicielem Rosji przy ASEAN jest Aleksander Iwanow. W Rosji powołano komitet ASEAN, skupiający ambasadorów Stowarzyszenia rezydujących w Moskwie. Na Uniwersytecie MGIMO powstało centrum ASEAN, które pełni rolę ekspercką dla MSZ. Od 2018 r. działa tu również sieć eksperckich centrów NARTT. Centrum ASEAN i Wietnamu istnieje również w Rosyjskiej Akademii Nauk.

Państwa ASEAN dostrzegały potencjał FR jako nowego mocarstwa w Azji (Thambipillai, 2012). Rosja z kolei zwróciła uwagę, że „średnie mocarstwa”, takie jak np. ASEAN, można i należy wykorzystać w procesie decyzyjnym wobec regionalnych problemów w regionie Azji i Pacyfiku. Dostrzeżono również szybki rozwój państw regionu. Rosji zależało na tym, żeby rozwijać relacje nie tylko z oddzielnymi państwami Azji Południowo-Wschodniej, ale z całym Stowarzyszeniem.

Między Rosją a ASEAN jest kilka kanałów kontaktu: szczyty Rosja-ASEAN, coroczne konferencje ministrów spraw zagranicznych i spotkania w formacie ASEAN+1, a także dialogowe partnerstwo ASEAN+10. Ważnym instrumentem konsultacji w zakresie bezpieczeństwa są spotkania ministrów obrony (ASEAN Defence Ministers Meeting+). Funkcjonują też grupy robocze w najbardziej perspektywicznych dziedzinach współpracy.

Najlepiej układa się współpraca w sprawach polityki regionalnej i konkretnych problemów związanych z zachowaniem pokoju w regionie Azji i Pacyfiku. Jednym $z$ takich problemów jest nierozprzestrzenianie broni atomowej w regionie. Należy pamiętać o próbach nuklearnych Korei Północnej. Rosja od dawna występuje za stworzeniem systemu bezpieczeństwa zbiorowego. Powoli te argumenty są przejmowane przez ASEAN (Lokshyn, 2010). Rosja od samego 
początku uczestniczy w ARF. Ważnym mechanizmem są tu wspomniane spotkania ministrów obrony i Rosja w tym formacie działa, przysyłając swoich ekspertów. Na forum ARF w Phuket w 2009 r. minister spraw zagranicznych Siergiej Ławrow zwracał uwagę na kolektywne podstawy bezpieczeństwa w oparciu o prawo międzynarodowe, konsultacje i dialog, co wzmacnia dyplomację prowadzoną w ramach ASEAN way.

Rosja i ASEAN współpracują w sprawie walki z terroryzmem, w tym w ramach ONZ. W 2004 r. w Dżakarcie została podpisana deklaracji ASEAN+ Rosja na temat wspólnej walki z terroryzmem. Przewidziano wymianę informacji. Powstała grupa robocza Rosja-ASEAN do walki z terroryzmem. Rozpoczął się mechanizm spotkań ekspertów w sprawie transnarodowej przestępczości. Współpracują służby wywiadowcze w ramach takich organizacji jak ASEANPOL. Kolejną dziedziną współpracy są klęski żywiołowe.

Perspektywiczną dziedziną współpracy jest energetyka. W 2010 r. w czasie spotkania grupy roboczej ds. energetyki ASEAN Senior Officials on Energy-Russia przyjęto program współpracy energetycznej. W deklaracji przyjętej na szczycie w Soczi (2016 r.) również podkreślono ważność wyżej wymienionych form współpracy gospodarczej oraz w takich gałęziach, jak: infrastruktura transportowa, energetyka, elektronika, współpraca technologiczna, przemysł naftowy, rolnictwo czy rybołówstwo (Final Soczi Declaration of the ASEANRussian Federation). Te dziedziny współpracy jako perspektywiczne zostały potwierdzone na szczycie w Singapurze (2018 r.)

Śledząc ewolucję stosunków wzajemnych, można stwierdzić, że o ile do początku XXI w. obserwować można niewielkie wzajemne zainteresowanie, to po 2014 r. w okresie ochłodzenia stosunków Rosji z Unią Europejską i Stanami Zjednoczonymi i nałożenia sankcji po interwencji na Ukrainie oraz aneksji Krymu rośnie zainteresowanie rozwijaniem relacji, zwłaszcza po stronie rosyjskiej. Podstawą jest to, że zarówno Rosja, jak i ASEAN chcą integrować się z gospodarką światową na swoich zasadach, innych od twardych reguł narzuconych prze WTO. ASEAN koordynuje szereg form dialogu, których uczestnicy omawiają problemy regionalnego bezpieczeństwa na konsensualnej podstawie - ASEAN way. Dla Rosji ASEAN to przykład norm i wartości, które są jej bliskie. To również ważny kierunek rosyjskiego powrotu do Azji i dywersyfikacji tego kierunku. Rosja zbyt wyraźnie jest identyfikowana jako bliski sojusznik Chin, co często jest poddawane krytyce ekspertów i naukowców w środowisku wewnętrznym. Wysiłki zmierzające zatem do podkreślania własnych niezależnych od Chin interesów sprzyjają poprawie jej wizerunku jako niezależnego, liczącego się gracza. 
Decyzję o podniesieniu rangi stosunków z ASEAN podjęto na szczycie w Soczi w maju 2016 r. i ostatecznie zatwierdzono na szczycie w Singapurze w 2018 r. (Joint Statement of the 3 ${ }^{\text {rd }}$ ASEAN-Russian Federation Summit on Strategic Partnership). Dla Rosji szczyt w Soczi był związany z zainicjowaniem koncepcji budowy makroregionu euroazjatyckiego (o którym szerzej w dalszej części artykułu), opartego na zintegrowaniu już zintegrowanych regionów: Unii Euroazjatyckiej, Szanghajskiej Organizacji Współpracy oraz ASEAN, a dla ASEAN z celami przyjętymi w ASEAN Community Blueprint i Master Plan on Connectivity 2025. Perspektywa dalszego integrowania regionu może być impulsem dla nowego otwarcia wzajemnych relacji.

\section{ASEAN I NOWY REGIONALIZM. SPOJRZENIE ROSJI NA POZYCJĘ STOWARZYSZENIA W NOWEJ STRUKTURZE MIĘDZYNARODOWEJ}

Aby wyjaśnić cele i okoliczności wypracowania koncepcji Wielkiej Euroazji w odniesieniu do ASEAN, warto odpowiedzieć na pytanie, jak eksperci rosyjscy oceniają rzeczywistość międzynarodową oraz korzyści płynące ze współpracy z Azją Południowo-Wschodnią.

Eksperci rosyjscy widzą Azję Południowo-Wschodnią i ASEAN jako ważną część regionu Azji i Pacyfiku, w którym największą rolę odgrywają dwa mocarstwa - Chiny i USA. Ich oddziaływanie ma jednak swoje ograniczenia: amerykańskie z powodu niemożności przełożenia siły militarnej na wpływy polityczne, a chińskie z tego powodu, że nie mogą wykorzystać należycie siły miękkiej, tak aby azjatyccy partnerzy wycofali poparcie dla Ameryki i przekierowali je w stronę Chin. Sergiej Karaganow zauważa, że zmniejsza się możliwość przewidywania rozwoju wydarzeń, rośnie konfliktogenność świata i niekontrolowany przypadkowy przebieg zdarzeń. Rozpoczął się proces przeformatowania albo nawet likwidacji systemu globalnego, zanika system konsensusu waszyngtońskiego (Karaganow, 2018). Rozwinięty świat będzie zmieniał swoją konfigurację w stronę dwubiegunowości i później lub wcześniej dołączą do niego Chiny, część ASEAN, Tajwan i Indie. Zanika podział na rozwinięty i nierozwinięty świat, a pojawia się podział na „stary zachód” i nowy „niezachód”. Widoczny jest wzrost Azji - dla kontynentu suwerennych i narodowych państw atrakcyjne stają się modele: Azja dla świata, Azja dla Azji. Wewnętrzny, azjatycki, głównie chiński rynek staje się źródłem ekonomicznego wzrostu regionu. 
Karganow pisze, że z powodu spadku poziomu gospodarczego, problemów związanych z izolacją i nałożonych sankcji Rosja nie jest w stanie gospodarczo wspierać i subsydiować swoich sojuszników (na obszarze byłego ZSRR), a takie integracyjne byty jak Związek Białorusi i Rosji czy Euroazjatycka Unia Gospodarcza (EAEU) potrzebują realnego wsparcia i wypełnienia treścią deklarowanych powiązań. Tak zdefiniowana sytuacja międzynarodowa każe Rosji poszukać nowych bodźców dla utrzymania i wzmocnienia integracyjnych więzi dla powrotu do gry w tym nowym „niezachodnim” świecie. Ideą, która pojawiała się wcześniej i wybrzmiała dobitnie po szczycie w Soczi (20.05 2016 r.) ASEAN+Rosja, stał się projekt euroazjatyckiego makroregionu. Rosji przede wszystkim zależy na stworzeniu strefy bezcłowej pomiędzy krajami ASEAN- u a Euroazjatycką Unią Gospodarczą (Eurasian Economic Union EAES): Wietnam taką umowę o wolnym handlu już podpisał, a w deklaracji w Soczi państwa ASEAN zgodziły się na podjęcie prac w tym kierunku ( Soczi Declaration - ASEAN).

Warto zaznaczyć w tym momencie, że sam projekt Wielkiej Euroazji przez wielu ekspertów rosyjskich jest traktowany jako odrębny od chińskiej koncepcji pasa i szlaku, ewentualnie rosyjskie uzupełnienie chińskiej idei i powrót Rosji do gry o Azję. Należy dodać, że wśród naukowców rosyjskich są różne opinie na temat przełożenia się koncepcji pasa i szlaku na korzyści dla Rosji - od entuzjastycznych i sugerujących, że powstanie infrastruktura i inwestycje, po pesymistyczne, sugerujące, że Chiny chcą zająć miejsce ZSRR w Azji Środkowej. Karaganov argumentował, że ta inicjatywa może zastąpić rosyjską Transsyberyjską Kolej oraz Północną Drogę Morską. Dla tych przyczyn rywalizacja między Rosja a Chinami jest nieunikniona (Timofeev, Lissovolik, Filippova, 2017). Dlatego też można uznać, że rosyjski projekt Euroazji odpowiada na obawy niektórych ekspertów rosyjskich, pokazuje zdolność Rosji do strategicznego planowania.

Idea makroregionu idzie dalej, bowiem pojawia się propozycja dialogu między UE a EAES, co dla Rosji byłoby spełnieniem wielowiekowych marzeń o Euroazję. Ta propozycja wpisuje się w koncepcję ASEAN ,integrować zintegrowane" i większość przytoczonych analiz ekspertów rosyjskich widzi korzyści nie tylko dla Rosji, ale całej Azji Południowo-Wschodniej. Koncepcja interegionalizmu zakłada obiektywny charakter procesu tworzenia makroregionów, a Azja Wschodnia charakteryzuje się szczególnym typem regionalizmu, który może doprowadzić do globalnej integracji, co wynika z teorii regionalizmu przedstawionego chociażby przez Baldwina i Kawaiego (Baldwin, Kawai, 2013). 
Warto przytoczyć inną argumentację na rzecz projektu Euroazji Antona Tsvietowa. Uważa on, że Rosja pozostająca z boku Regionalnego Partnerstwa Ekonomicznego (Regional Comprehensive Economic Partnership RCEP), mogłaby się aktywnie włączyć w porozumienia wolnocłowe (FTA) poprzez Euroazjatycką Unię Gospodarczą i stać się stroną RCEP lub innej handlowej organizacji tego typu, wykorzystując EAEU (Tsvetov, 2018). Impulsem do bardziej aktywnej dyplomacji w tym kierunku było wyjście USA z Partnerstwa Transpacyficznego (Trans Pacific Partnership TPP). Rosja mogła zaproponować inny, wykraczający poza dotychczasową formułę projekt ekonomicznego partnerstwa między EAEU, Szanghajską Organizacją Współpracy (Shanghai Cooperation Organization SCO) i ASEAN. Na czym dokładnie ma polegać idea? Zdaniem Tsvietowa na razie koncepcja nie jest zarysowana konkretnie, ale uważa, że jest to przede wszystkim pokazanie zdolności Rosji do włączenia się w projekty globalne, zgodne z przyjętą przez ASEAN niezachodnią liberalizacją oparta na preferencyjnym handlu.

Odpowiedź na pytanie, jak Rosja postrzega ASEAN, można znaleźć w analizach innych ekspertów ds. regionu. A.W. Lukin zauważa, że umacniają się organizacje, które z zachodnim sposobem gospodarowania mają mało wspólnego i podaje przykład ASEAN (Lukin, 2018). Podobny pogląd wyraża Ewgienij Kanajev, który podkreśla, że liderzy ASEAN wskazują na niemożność zastosowania modelu europejskiego w regionie Azji i Pacyfiku (Kanajev, 2018). W przypadku Rosji izolowanej przez Zachód może to być szansa na rozwój. Lukin zwraca uwagę na postępujący proces centralizacji ASEAN i dostrzega, że w jego ramach mogą pojawiać się nowe centra regionalne, np. Wietnam, który będzie szukał dla siebie mocnych sojuszników, aby tworzyć czasowe alianse. Wietnam np. próbuje wykorzystać USA dla poparcia w terytorialnym sporze z Chinami. Lukin nazywa ten system systemem postbipolarnym. Wzrost konfliktogenności współczesnego świata pojawia się w większości analiz.

Rosja oprócz wsparcia dla nowych nieliberalnych idei globalizacji wspiera ASEAN w polityce balansowania, asekuracji (hedging). Różnorodność kontaktów Rosji z państwami Azji Południowo-Wschodniej (ARF, APEC, EAS ASEM) pozwala sformułować tezę, że jest to raczej działanie na zdywersyfikowanie „reorientacji” na Azję niż balansowanie przeciw komukolwiek, co dla ASEAN nie jest bez znaczenia. W regionie są napięcia między ASEAN a Chinami i dlatego Moskwa pokazuje, że jest w stanie stosować strategię hedging dla siebie, jak i dla innych (Korolev, 2018).

Podsumowując tę część rozważań, należy podkreślić, że eksperci rosyjscy zdają sobie sprawę z rosnącego znaczenia regionu Azji Południowo-Wschodniej 
w relacjach regionalnych, ale i coraz bardziej globalnych. W wielu wypowiedziach i ekspertyzach pojawia się teza, że Rosja nie może się uzależnić od Chin, musi dywersyfikować partnerów. Makroregion euroazjatycki optymalizuje realizację interesów zarówno ASEAN, jak i Rosji. ASEAN ma doświadczenie, w jaki sposób układać współpracę wielkich graczy w czasie wielostronnych rozmów na neutralnej bazie i wydaje się, że szczegóły zgłoszonej przez prezydenta Putina idei mogą być konkretyzowane z jej udziałem. ASEAN stara się wpłynąć na system globalny. Rośnie liczba umów o wolnym handlu, Azja Południowo-Wschodnia jest rozpatrywana jako obowiązkowy kierunek współpracy w regionie Azji i Pacyfiku, zatem projekt RCEP (Żołądkiewicz, 2016), do którego należą ważniejsze mocarstwa regionalne: Australia, Chiny, Indie, Japonia, Korea Płd. i Nowa Zelandia, staje się dodatkowym instrumentem rozwoju i może mieć wpływ na uzdrowienie koniunktury. Ten kierunek regionalizmu inny od twardych reguł narzuconych prze WTO staje się, jak pisze Żołądkiewicz: „jednym z głównych instrumentów liberalizacji handlu światowego" (Żołądkiewicz, 2016) i odpowiadającym azjatyckiej specyfice, dodajmy - rosyjskiej również.

Rosja natomiast może optymalnie integrować euroazjatycki i azjatycko-pacyficzny kierunek swojej polityki zagranicznej i sprawić, by był kompleksowy, wielostronny, bardziej efektywny i dać impuls swojej polityce pivot to Asia. U Rosji i ASEAN po raz pierwszy w historii pojawiła się silna motywacja do współpracy. Zbudowanie nowych instytucji pozwoli przezwyciężyć stagnację we wzajemnych relacjach. Na czym zatem ma polegać idea Wielkiej Euroazji? Na pewno podstawą jest zbliżenie Rosji i Chin, ale nie na podyktowanych przez Chiny warunkach. Dużą rolę w tym zbliżeniu odgrywają inne niezachodnie organizacje. Euroazja ma pomijać Stany Zjednoczone i jednocześnie szanować różnice kulturowe, zgodnie z cały czas obowiązującą Deklaracją w Bandungu w 1955 r. W tym znaczeniu makroregion ma spełniać wymogi ASEAN way, „niezachodniej” ścieżki rozwoju państw i pluralizmu. Jeśli chodzi o interesy gospodarcze, to jest możliwe stworzenie strefy wolnocłowej na zasadzie poszerzenia RCEP, a także w ramach EAEU. Ważne i możliwe jest stworzenie nowych korytarzy, w tym Morskiego Jedwabnego Szlaku łączącego Euroazję z ASEAN, oraz szerszego wykorzystania Północnego Szlaku Morskiego, co leży w interesie Rosji.

Rosja liczy na to, że wspólne profity, wynikające z projektu, zachęcą ASEAN do pozytywnego włączenia się do dyskusji. Na jakie zalety wskazują rosyjscy eksperci? Najczęściej wymieniane są następujące: odwołuje się do dużej przestrzeni, będzie wymagał sporych nakładów w infrastrukturę lądową i morską z udziałem ASEAN, Rosji i Chin, co może pobudzić gospodarki. Rosji będzie 
dawał możliwość włączenia Syberii i RDW do regionu, co przecież jest jednym z celów azjatyckiej polityki Rosji. ASEAN-owi może przynieść osłabienie i wyciszenie konfliktów w rejonie Morza Południowochińskiego, bowiem centrum aktywności gospodarczej przemieści się z regionu Azji i Pacyfiku do regionu Euroazji. Wyłoni się nowa struktura bezpieczeństwa, a Euroazja może stać się jednym z centrów multilateralnego świata. ASEAN wzmocni swój dialog, swoją globalną pozycję i nie będzie musiało się bezpośrednio konfrontować z Chinami. Inicjatywa obliczona jest na przyszłość.

Oceniając opinie rosyjskich ekspertów, można stwierdzić, że w dzisiejszych warunkach rosyjska strategia pivot to Greater Euroasian Partnership jest mało realna, zwłaszcza z powodu gospodarczych ograniczeń Rosji. Została sformułowana, aby Rosja nie wypadła z gry i aby nie postrzegać kierunku pivot to Asia jako pivot to China (Gabuev, 2015). Odwrócenie uwagi od konfliktu na Morzu Południowochińskim projektem euroazjatyckim jest mrzonką. Nie należy jednak jej traktować li tylko jako element propagandy, ale perspektywiczny, choć trudny do realizacji projekt. Chociaż w gronie partnerów z ASEAN brak jest wyraźnego poparcia dla projektu, to jednak w Deklaracji Singapurskiej nawiązano do idei proponowanej w Soczi przez prezydenta Putina. Co prawda koncepcja została zmodyfikowana, między innymi w ten sposób, że zaproponowano rozdzielenie rozmów o współpracy ASEAN z SCO i ASEAN z EAEU, nie pojawiała się nazwa Wielkiej Euroazji, ale rozmowy na temat poszerzenia integracji z udziałem ASEAN i partnerów euroazjatyckich mają się toczyć. Jeden z członków ASEAN - Wietnam - podpisał już umowę z EAEU (Free Trade Agreement Between the EAEU and Vietnam), która weszła w życie 5 października 2016 r.

\section{OGRANICZENIA WSPÓŁPRACY DWUSTRONNEJ}

Najczęściej pojawiająca się konstatacja dotycząca relacji Rosji i ASEAN jest taka, że nie odpowiada potencjałowi, jaki mógłby się kryć za tymi relacjami. Aktywizacja następuje przed kolejną okrągłą datą, a potem wszystko wraca na stare, nieefektywne tory. Dlatego też przywoływany już w artykule Kanajev uważa, że należy cały ten system, na którym budowane są relacje, zmienić (Kanajev, 2018). Zmiana może być jednak trudna, bowiem na przeszkodzie stoi szereg niepokojących zjawisk.

Największym problemem w relacjach Rosja-ASEAN jest praktyczna nieobecność Rosji w świadomości grup biznesowych, elit zarządzających i intelektual- 
nych: nie ma tu diaspor rosyjskich, branding rosyjski (marka) praktycznie nie istnieje, słabe są możliwości polityki kredytowej Rosji. Rosja nie wypracowała tradycji współpracy z państwami regionu, poza Wietnamem z okresu wojen indochińskich, ale obecnie te formy również są przestarzałe.

Do tego dochodzi efekt antyrosyjskich sankcji. Sankcje spowodowały zachwianie systemu bankowego i nawet w Azji Wschodniej, gdzie państwa w większości się do nich nie przyłączały, nie ryzykowały inwestycji z tego właśnie powodu. Nawet chińskie banki zachowywały ostrożność w tej sytuacji. Te problemy noszą charakter długoterminowy i nie mogą być naprawione w krótkim czasie.

Pomimo deklaracji Rosja nadal ma słabe związki gospodarcze z Azją Południowo-Wschodnią i oprócz tradycyjnych sfer, jak np.: ropa, gaz, przemysł ciężki, nuklearna technologia, nie ma nic do zaproponowania. Rosja może zaoferować korzystanie $\mathrm{z}$ alternatywnych tras przesyłowych przez magistralę transsyberyjską i Północny Szlak Morski, ale one nie są wykorzystywane dostatecznie, np. w latach 2015 i 2016 przez Północny Szlak Morski zrealizowano odpowiednio 18 i 19 przejść statków (Kanajev, 2017). Ślimaczą się również inwestycje związane z energetyką atomową - Wietnam sześć lat po rozpoczęciu budowy wstrzymał budowę elektrowni atomowej formalnie z przyczyn ekonomicznych, ale najprawdopodobniej również politycznych (Koldunova, 2018).

Dane gospodarcze dotyczące współpracy są złe. Rosja kładzie akcent na 3 państwa: Wietnam, Indonezję i Malezję. Są to tradycyjni partnerzy w regionie, a nowych nie przybywa, poza Singapurem, w ostatnim okresie. Obrót towarowy cały czas jest mały. Struktura handlu nie zmienia, się eksport Rosji do ASEAN jest ograniczony i monotonny Większość to surowce energetyczne, metalurgia, chemia, papier i celuloza. Udział maszyn i urządzeń w eksporcie nie zwiększa się. W ASEAN Rosja kupuje tradycyjnie kauczuk, lateks, olej kokosowy i palmowy, towary codziennego użytku, domową elektronikę. Jak do tej pory, próby wejścia na rynek ASEAN rosyjskiej techniki kosmicznej były nieudane (Telkom-3/Ekspress-MD2 launch failure). Poniższe tabele przedstawiają rozwój współpracy między dwoma podmiotami na tle innych partnerów dialogu. Cały czas ASEAN ma deficyt w handlu z Rosją, w $2016 \mathrm{r}$ wyniósł on $-2392,4 \mathrm{mln}$ USD, a poziom obrotu towarowego pozostaje niski i utrzymuje się na poziomie handlu Kanady z ASEAN. Jeżeli weźmiemy pod uwagę fakt, że dla ASEAN najważniejszą kwestią jest regionalizacja ekonomiczna, to zdecydowanie ten czynnik komplikuje współpracę, mimo licznych deklaracji na rzecz jej rozwoju. 
Tabela 1. Eksport ASEAN do państw dialogu w mln USD

\begin{tabular}{|c|c|c|c|c|c|c|c|c|c|c|}
\hline rok & Australia & Kanada & Chiny & UE(28) & Indie & Japonia & $\begin{array}{c}\text { Korea } \\
\text { Pd }\end{array}$ & $\begin{array}{c}\text { Nowa } \\
\text { Zelandia }\end{array}$ & Rosja & USA \\
\hline 1994 & 4512 & 2155 & 5304 & 35196 & 1990 & 34300 & 7005 & 697 & 159 & 49371 \\
\hline 2000 & 8893 & 2707 & 14179 & 63474 & 6447 & 50560 & 14454 & 1213 & 327 & 73770 \\
\hline 2005 & 19636 & 3140 & 52232 & 81051 & 15047 & 72750 & 24357 & 2634 & 1469 & 92929 \\
\hline 2010 & 35221 & 5200 & 112917 & 115080 & 35991 & 102851 & 44947 & 4243 & 2589 & 100402 \\
\hline 2014 & 45345 & 7470 & 150407 & 132484 & 43326 & 120224 & 51624 & 6381 & 5415 & 122375 \\
\hline 2016 & 32993 & 7394 & 143519 & 130415 & 37634 & 96037 & 45711 & 4547 & 4782 & 131071 \\
\hline
\end{tabular}

Źródło: ASEAN Yearbook on International Merchandise Trade in Goods; ASEAN Statistical Yearbook 2016/17.

Tabela 2. Import ASEAN z państw dialogu w mln USD

\begin{tabular}{|c|c|c|c|c|c|c|c|c|c|c|}
\hline rok & Australia & Kanada & Chiny & UE(28) & Indie & Japonia & $\begin{array}{c}\text { Korea } \\
\text { Pd }\end{array}$ & $\begin{array}{c}\text { Nowa } \\
\text { Zelandia }\end{array}$ & Rosja & USA \\
\hline 1994 & 6447 & 1717 & 5759 & 38729 & 1547 & 67302 & 9036 & 798 & 496 & 39202 \\
\hline 2000 & 8695 & 2126 & 18137 & 39297 & 3210 & 65631 & 15181 & 1035 & 1048 & 48448 \\
\hline 2005 & 11589 & 2832 & 6114 & 59681 & 7961 & 81072 & 23601 & 1456 & 3234 & 60955 \\
\hline 2010 & 14807 & 3539 & 96622 & 78717 & 12575 & 82832 & 40479 & 2242 & 5113 & 66702 \\
\hline 2014 & 25029 & 5685 & 216119 & 115824 & 24382 & 108818 & 79815 & 4326 & 17128 & 90054 \\
\hline 2016 & 19795 & 5237 & 224508 & 103146 & 20815 & 105856 & 78540 & 3353 & 7174 & 80730 \\
\hline
\end{tabular}

Źródło: ASEAN Yearbook on International Merchandise Trade in Goods; ASEAN Statistical Yearbook 2016/17.

Istnieje jednak możliwość - ale dzieje się to powoli - przyciągnięcia kapitału ASEAN do sfery usług, przemysłu naftowego, budownictwa i realizacji programów rozwoju Syberii i Dalekiego Wschodu (Voronin, Kozłov, 2010). W Rosji na przykład firmy wietnamskie inwestycją w przemysł wydobywczy. Oprócz firm inwestujących w przemysł naftowy i gazowy firmy wietnamskie produkują węglowodór i przygotowują go do eksportu do Wietnamu. Szacuje się, że firmy wietnamskie ulokowały swój kapitał podobnie w wysokości ok. 1 mld USD. Wietnam otrzymał kredyt rosyjski na sumę ok. 10 mld USD (Lokszyn, 2010).

Nową formą współpracy jest rozwój więzi międzyregionalnych. W czasie rozmów w 2008 r. prezydent Wietnamu Nguyen Minh Triet zaproponował współpracę z wietnamskimi prowincjami. Już teraz działa wspólne przedsiębiorstwo Rusvietpetro w Nienieckim okręgu autonomicznym, a duże nadzieje związane są 
z działalnością innej spółki joint ventures Gazpromviet, która rozpoczęła prace poszukiwawcze ropy i gazu w obwodzie orenburskim (Pietrov). Dla Rosji przecież inspiracją dla ściślejszych związków z regionem jest rozwój Syberii i RDW. To, co spowalnia wzrost współpracy gospodarczej, to infrastruktura logistyczna i transport. Jak było wspomniane wcześniej, postuluje się rozwój transportu morskiego i wykorzystanie portów rosyjskich na RDW. Perspektywiczne plany wobec ASEAN widziane są w kontekście wizji euroazjatyckiej. Rosja jest też zainteresowana transportem kolejowym. Projekt Transazjatyckiej drogi kolejowej od Turcji do Singapuru został opracowany przez ESKATO ONZ. Uczestnikiem projektu są Chiny. Ma to być sieć, na którą składać się będzie 81 tys. km i części: Północna (Korea-Rosja-Chiny-Mongolia-Kazachstan) Południowa (Pd. ChinyMianma, Indie-Iran, Turcja) Północ-Południe (Rosja-Azja Centralna-region Zatoki Perskiej) oraz Chiny-ASEAN. Są też projekty dróg i autostrad oraz połączeń lotniczych. Jeżeli te projekty zostaną zrealizowane, jedna z większych przeszkód logistycznych zostanie zlikwidowana, ale na to potrzebny jest czas i środki finansowe.

Eksperci rosyjscy zwracają uwagę na to, że problematyczny jest rozwój prywatnego biznesu na rynkach ASEAN i postulują zwiększenie obecności dużych firm rosyjskich w Azji Południowo-Wschodniej, doskonalenie systemu ubezpieczeń i obsługi arbitrażowej, włączenie przedstawicieli tych dużych, zainteresowanych współpracą firm do dwustronnych międzyrządowych grup roboczych i komisji tak, aby rządy mogły szybciej reagować na problemy, które się pojawiają w biznesie; wreszcie doskonalenie bazy prawnej, aby właściwie reagować na problemy na styku państwo-przedsiębiorstwo, biznes-nauka. Powinny powstawać instytuty naukowe, reżimy preferencji celnych i kredytowych dla małych przedsiębiorstw (Voronin, Kozłov, 2010). Postulaty sformułowane w pierwszej dekadzie XXI w. i obecnie pozostają niezrealizowane.

Oprócz współpracy gospodarczej przeszkodą na drodze do realizacji nowych form współpracy są kwestie polityczne i bezpieczeństwa, w tym konflikt na Morzu Południowochińskim. Jeśli chodzi o konflikt na Morzu Południowochińskim, to formalnie nie jest to przedmiot wspólnego zainteresowania ASEAN (Lokszyn, 2016); nie wszystkie państwa ASEAN wysuwają roszczenia wobec wysp na Morzu Południowochińskim, ale podkreślić należy, że jest to jeden z najbardziej groźnych współczesnych sporów terytorialnych. Dla Rosji ten spór jest częścią geopolitycznej gry. Imperatyw systemowego balansowania pcha Rosję w stronę Chin, co pozwala na walkę z unipolarnym światem (Korolev, 2018). Rosja jest przeciw internacjonalizacji sporu i działa typowo dla sytuacji, gdy chce powstrzy- 
mać któreś $\mathrm{z}$ mocarstw. W tym wypadku formalnie jest neutralna, w praktyce wspólnie z Chinami równoważy wpływy amerykańskie. Rosja ma również dobre relacje z Wietnamem, głównym oponentem Chin w tym konflikcie, i dopóki będzie utrzymywać dobre relacje zarówno z Chinami, jak i Wietnamem, dopóty będzie w stanie chociażby zachowywać pozory neutralności. Po werdykcie Sądu w Hadze z 12 czerwca 2016 r., który przyznał rację Filipinom i wypowiedział się przeciw argumentacji Chin, sytuacja zdaniem wielu ekspertów rosyjskich pogorszyła się. Kanajev uważa, że może to rodzić nowe nacjonalizmy. Lokshyn przypomina, że niezależnie od oceny państw jest to werdykt sądu i trzeba go traktować bardzo poważnie. Zatem należy podkreślić, że Rosja mogłaby odgrywać większą rolę w rozwiązaniu sporu, ale tego nie robi. Z całą pewnością strategia hedging, asekuracja Rosji nie wzmacnia jej pozycji w regionie jako niezależnego gracza. Dla ASEAN Rosja jest ważna dla wzmacniania więzów wewnątrz ASEAN również w kierunku relacji z mocarstwami. Jednak jej strategia jest mało konkretna i często, co już zostało powiedziane, ma charakter okazjonalny, a chiński kierunek polityki aż nazbyt widoczny.

Szereg utrudnień związanych z rozwojem wzajemnych stosunków wynika z przyczyn niezależnych od polityki rosyjskiej. Obserwujemy na przykład narastającą dysproporcję między zwiększeniem wzajemnej zależności i elementów policentryczności w gospodarce światowej i zmniejszeniem efektywności regulujących to wszystko instytucji. Jeśli chodzi o ASEAN, to obserwujemy dużo formatów i brak konkretów, nowe propozycje toną w morzu rozmów i spotkań. Kolejnym problemem było to, że nie tylko Rosja, ale i pozostałe mocarstwa zintensyfikowały swoją politykę wobec Azji Południowo-Wschodniej - konkurencja jest duża, ale wspólnej polityki wobec tych mocarstw ASEAN nie wypracowało. W praktyce, jeśli chodzi o partnerów dialogu, to widoczny jest trójstopniowy model. Na najwyższym stopniu znajdują się USA. Dla większości członków to USA są gwarantem bezpieczeństwa. Na drugim stopniu są Chiny, w dialogu z którymi ASEAN szuka zrównoważenia. Na trzecim stopniu sytuują się pozostali partnerzy dialogu: Japonia, Indie, Australia, Korea i Rosja, a także UE (Kanajev, 2018). Dla większości członków ASEAN celem było zbalansowanie wpływów USA i Chin oraz przygotowanie projektu RWEP, a przecież, jak do tej pory, Rosji w tym projekcie nie ma. Warto też zauważyć, że aseanocentryczność zakłada inicjowanie kierunków integracyjnych i makrostruktur, w przypadku projektu Wielkiej Euroazji inicjatywa wychodzi z zewnątrz ugrupowania, zatem w grę wchodzi umiejętność przekonania partnerów co do jej celowości. 
Podsumowując rozważania na temat perspektyw formatu ASEAN+Rosja i możliwości wpływania przez Rosję na procesy regionalizacji w Azji Południowo-Wschodniej, należy podkreślić, że hipoteza badawcza, zakładająca, że Rosja jest elementem geopolitycznej gry w regionie Azji Południowo-Wschodniej, została pozytywnie zweryfikowana, choć podkreślić należy, że nie jest ona ważnym partnerem dla ASEAN. Podstawą współpracy pozostają kwestie dostaw ropy naftowej i gazu ziemnego oraz broni. Rosja podejmuje jednak starania, aby swoją pozycję w regionie wzmocnić. Takim projektem jest budowa Wielkiej Euroazji, która wychodzi naprzeciw projektom budowania nowych struktur integracyjnych Azji Wschodniej na bazie centralizmu ASEAN. Jest to dowód na to, że Rosja traktuje ASEAN jako jednolitego gracza, sprzyja centralizmowi tej organizacji i działa na rzecz integracji regionu z jej obecnością. Neutralna postawa wobec konfliktu na Morzu Południowochińskim, mimo że w praktyce odczytywana jako prochińska, sprzyja stabilizacji. Wreszcie należy wziąć pod uwagę, że rola balansowania wpływów wielkich mocarstw Chin i USA, czego oczekuje ASEAN od swoich partnerów, również jest trudna do wykonania, co najwyżej Rosji pozostaje równoważyć wpływy amerykańskie wspólnie z Chinami. Rosja jest postrzegana jako bliski sojusznik Chin, ale w odniesieniu do ASEAN oba państwa nie wypracowują wspólnej strategii, w niektórych obszarach ich interesy są sprzeczne. Przed uzależnieniem się od Chin przestrzegają rosyjscy eksperci. Rosja chce być postrzegana jako partner niezależny, a ASEAN w tym kontekście jest elementem dywersyfikującym kierunki jej polityki zagranicznej.

\section{BiBLIOGRAFIA:}

ASEAN Statistical Yearbook 2016/17. (2017). Pobrane z: https://asean.org/storage/2018/01/ASYB_2017-rev.pdf.

ASEAN Yearbook on International Merchandise Trade in Goods (IMTS). (2016). Pobrane z: https://www.aseanstats.org/wp-content/uploads/2016/11/ASEAN-IMTS-2015_hires-1.pdf.

Baldwin, R., Kawai, M. (2013). Multilateralizing Asian Regionalizm. ADBI Working Paper Series, ADBInstitute nr.431. Pobrane z: https://www.adb.org/sites/default/files/ publication/156286/adbi-wp431.pdf

Final Soczi Declaration of the ASEAN-Russian Federation Commemorative Summit to Mark the $20^{\text {th }}$ Anniversary of ASEAN-Russian Federation Dialogue Partnership "Moving Towards a Strategic Partnership for Mutual Benefit". (2018). Pobrane z: https://www.asean.org/storage/2016/05/SD-of-the-ASEAN-Russia-CommSummit-Final.pdf. 
Free Trade Agreement Between the EAEU and Vietnam. (2015). Pobrane z: http:// www.eurasiancommission.org/ru/act/trade/dotp/sogl_torg/Documents/EAEU-VN_FTA.pdf.

Gabuev, A. (2015). A "Soft Alliance"? Russia-China Relations after the Ukraine Crisis, European Council on Foreign Relations. Pobrane z: http://lea.vitis.uspnet.usp.br/ arquivos/a-soft-alliance-russia-china-relations-after-the-ukraine-crisis_alexander-gabuev.pdf.

Ha Anh Tuan, (2008). Balance of Power of Southeast Asian Countries: The Origin of Peace and Autonomy in the Post-Cold War Era. W: S. Wilmar, S. Kiran (red.). Sustaining a Resilient Asia Pacific Community. Cambridge: Cambridge Scholars Publishing.

Hanggi, H. (2000). Interegionalism: Empirical and Theoretical Perspectives. Paper prepared for workshop, May 18. Los Angeles, CA. Pobrane z: https://www.cap. lmu.de/transatlantic/download/Haenggi.PDF. Joint Statement of the $3^{\text {rd }}$ ASEAN-Russian Federation Summit on Strategic Partnership. (2018). Pobrane z: https:// www.mfa.gov.sg/content/mfa/overseasmission/asean/press_statements_speeches/2018-01/2018-11/Press_2018-11-144.html.

Kanajev, E.A. (2017). Probliema Juzhniekitajskogo mira Novyje kategorii analiza. Jugovostochnaja Azja: aktualnyje problemy razvitija, 35, 32-44.

Kanajev, E.A. (2018). Formirujusheeca evroazjatickoje izmirienije otnoshenii Rossii. W: A.W. Lukin (red.). Nowyje mieźdunarodnyje otnoshenija. Osnownyje tendencji i wyzowy dla Rossii (s. 471-494). Moskwa: Miezhdunarodnyje Otnoshenija.

Karaganov, S. (2018). Mieżdunarodnyje tendencjii i rossijskaja wnieshniaja politika. W: A.W. Lukin (red.). Nowyje mieźdunarodnyje otnoshenija. Osnownyje tendencji i wyzowy dlia Rossii (12-29). Moskwa: Miezhdunarodnyje Otnoshenija.

Koldunova, E. (2018). ASEAN, WAS i ATES, Chto udalos sdielat'Rossii w 2018 godu. Pobrane z: http://russiancouncil.ru/analytics-and-comments/analytics/asean-vasi-ates-chto-udalos-sdelat-rossii-v-2018-godu/.

Korolev, A. (2018). Russia in the South China Sea: Balancing and Hedging. Foreign Policy Analysis. DOI: 10.1093/fpa/orx015.

Lokshyn, G.M. (2010). Dialogovoje Partnerstwo Rossija-ASEAN: Sotrudnichestvo w sfierie politiki i biezopasnosti. W: E.V. Kobielev, G.M. Lokshyn, N.P. Maletin (red.). ASEAN w nachale XXI w. (s. 298-308). Moskwa: „Forum”.

Lokshyn, G.M. (2016). ASEAN i territorialnyje spory w jużnokitajskom morie. W: W.M. Mazyrin, Novyje vyzowy i mechanizmy bezopasnosti w Vostochnoj Azji (s. 392-412). Moskwa: „Forum”.

Lukin, A.W.(2018). Postbipolarnyj mir: rozhdienije novovo miroporiadka ili pogrużenije w chaos?. W: A.W. Lukin (red.). Nowyje mieźdunarodnyje otnoshenija. Osnownyje tendencji i wyzowy dlia Rossii (s. 30-51). Moskwa: Miezhdunarodnyje Otnoshenija.

Overview ASEAN-Russia Dialogue Relations. (2018). Pobrane z: https://asean.org/ wp-content/uploads/2012/05/Overview-ASEAN-Russia-Dialogue-Relations.pdf. 
Pietrov, I. (2013). Rossija vozvrashchajetsa vo Vietnam. Pobrane z: http://www.km.ru/ economics/2013/11/13/vladimir-putin/725140-rossiya-vozvrashchaetsya-vovetnam.

Severino, R., Thuzar, M. (2012). ASEAN Regionalism and the Future of ASEAN-Russia Relations. W: V. Sumsky, M. Hong, A. Lugg (red.). ASEAN-Russia. Foundations and Future prospects (22-30). Singapore: ISEAS. Telkom-3/Ekspress-MD2 launch failure. (2012) Pobrane z: http://www.russianspaceweb.com/proton_telkom3.html. Thambipillai, P. (2012). Southeast Asia and Russia: Forging a new Regional Architecture. W: V. Sumsky, M. Hong, A. Lugg (red.). ASEAN-Russia. Foundations and Future Prospects (110-123). Singapore: ISEAS. Timofeev, I., Lissovolik, Y., Filippova, L., (2017). Vision of the Belt and Road Initiative: From the Rivalry of the Great Powers to Forging a New Cooperation Model In Eurasia. ChinaఓWorld Economy, 25(5), $62-77$.

Tsvetov, A. (2017). Russia's Asian Trade game. Pobrane z: https://thediplomat.com/tag/ russia-asia-relations/.

Voronin, A.S., Kozłov, A.A. (2010). Rossija-ASEAN: k otnoshenijam rozvitogo i vsieobemlushchego partnerstwa. W: E.V. Kobielev, G.M. Lokshyn, N.P. Maletin (red.). ASEAN w nachale XXI w. (s. 309-338). Moskwa: „Forum”.

Żoładkiewicz, K. (2016). Wszechstronne Regionalne Partnerstwo Ekonomiczne (RCEP) jako przykład nowego trendu w regionalizmie. Finanse, Rynki Finansowe, Ubezpieczenia.

Problemy współczesnej gospodarki światowej,3(81), 335-344. DOI: 10.18276/frfu.2016.81-29. 